\title{
Tema: sekularisering og sakralisering
}

Nogle gange kan det være godt at hælde gammel vin på nye flasker eller at fylde gamle flasker op med ny vin. Ikke bare fordi det generelt er vigtigt kontinuerligt at undersøge brede begreber og store teorier, men også fordi empiriske kontekster er under konstant forandring og derved kan udfordre teorierne.

Hvordan og i hvilken grad og udformning sekularisering er indtruffet, er et forskningsområde, der langt fra er udtømt. Der er ret klare indicier for, at religion i moderniteten i den vestlige verden har mistet autoritet. Gud er måske ikke helt død i hverken Nietschze'sk eller Steve Bruce'sk forstand, og måske er Skandinavien bare endnu en special case. Men sekulariseringens manglende universelle gyldighed berettiger ikke til en afvisning af sekulariseringsteorier, som trods alt er ganske brugbare og i hvert fald lokalt empirisk evidente. At den er forekommende, skal der stærkt ideologiske briller til for at benægte, og religiøse interesser i at afskrive sekulariseringsteorier som fejl- og kortslutninger hører naturligvis også til det religionsvidenskabelige forskningsfelt. Omvendt har mange religionsforskere og teologer kunnet påpege, at tidligere monolitiske og teleologiske sekulariseringsteser har vist sig ikke at holde vand som universelt, empirisk applicérbare. Når religion differentieres fra andre felter eller privatliggøres, siger det ikke nødvendigvis kun noget om dens vigende autoritet, men også om dens mulige forandring i 'postsekulære' eller 'postmaterielle' samfund. Der kan være gode grunde til at betragte religionssociologiske oneliners som 'believing without belonging", 'belonging without believing', den typisk asiatiske 'practicing without neither believing or belonging' eller bare 'spiritual, but not religious' som også ganske gedigne klangflader for moderne religion. Ikke mindst transformationen fra traditionel, kirkebaseret og kollektivt sanktioneret religiøsitet til 'den subjektive vending' med fokus på subjektiv autenticitet og individbaseret spiritualitet er en tendens, der empirisk har været målbar og genstand for teoretisering med tesen om 'den spirituelle revolution'. I det hele taget har der de sidste årtier fra religionsforskningens side været ret klare udtryk for, at religion og sakralisering forekommer ikke bare globalt (endog i stigende omfang), men også i den vestlige moderne verden. Enten fordi den aldrig helt har været væk; eller fordi den er kommet igen med et univers af genfortryllelse og gentraditionalisering.

Det interessante for forskeren inden for feltet samtidsreligion er derfor ikke kun, om der foreligger sekularisering eller sakralisering, for der er tale om begge, og ingen af dem synes nødvendigvis at være irreversible eller indbyrdes inkommensurable. Dette gælder for så vidt også på individniveau, for som en af artiklerne i dette temanummer en passant nævner, så er de fleste mennesker hverken utvetydigt 'religiøse' 
eller 'sekulære'. Spørgsmålene, der for alvor lægger op til interessante overvejelser er, hvordan og hvorfor 'mere eller mindre' religion og religiøsitet giver sig udtryk på forskellig vis. Som Heelas \& Woodhead har formuleret det: "the holy grail of the contemporary study of religion" er "why some forms of religion seem to be on the decrease while others seem to be increasing." (Heelas \& Woodhead The Spiritual Revolution. Why Religion is giving Way to Spirituality, Blackwell Publishing, Oxford 2005, 2).

Det var det fælles tema for workshoppen på Center for SamtidsReligion: Sacralization and secularization. The bearing of religious and spiritual authority in late modernity.

Indbudte forskere blev bedt om at reflektere over disse temaer, og ikke mindst mulige sammenhænge mellem dem. Nogle af oplæggene er her præsenteret som artikler.

Linda Woodhead stiller spørgsmålstegn ved antagelsen om, at sekularisering nødvendigvis hænger sammen med social differentiering og privatisering. Hun plæderer for, at offentlig religion (public religion) også uden for relationen til stat, kirke og civilsamfund bedst forstås via andre domæner (såsom intimsfære, politisk sfære, mediesfære, etc.), der fungerer som konkurrerende sekulære og religiøse kræfter. Hun foreslår teoretiske refleksioner omkring dette og præsenterer en model til videre empiriske analyser. Hans Raun Iversen tager temperaturen på "sekulariseringens betydning og religionens beskaffenhed" i dagens Danmark. Efter et historisk rids og teoretiske refleksioner omkring sekulariseringsbegrebet (med referencer til især Charles Taylor og Jürgen Habermas) udstiller han, med empirisk belæg, kompleksiteten ved begreberne religion og sekularitet ved karakteristikken af danskernes hovedreligion som "agnostisk deisme, der i krisesituationer kommer til udtryk for eksistentiel polydoksi". Margit Warburg har forskellige steder i verden undersøgt danske udlandskirker. I artiklen viser hun, hvordan kirkerne i Argentina, Rotterdam og Singapore anvendes som dansk-nationale fællesskaber, hvor stat, erhvervsliv og civilsamfund udspilles i det religiøse og sociale rum. Ud over at dokumentere en parallel til den aktuelle migrationsforsknings fokus på deres vej til os viser hun således, hvordan hellige og verdslige rum overlapper, også i en dansk diaspora. Jørn Borup undersøger japansk-amerikansk diaspora-buddhisme i en landsby på Hawaii. Religionens svindende betydning sættes i historisk perspektiv, men relateres også til det pluralistiske marked. Parallelt med sekularisering inden for én gruppe og én type religiøsitet vises ligeså klare sakraliseringstendenser inden for andre typer, begrundet med kausale relationer mellem historie, etnicitet og 'den subjektive vending'.

Jørn Borup 